Section Editors

David C. Spencer, MD

Steven Karceski, MD

\title{
Juvenile myoclonic epilepsy, a common epilepsy syndrome
}

WHAT WAS THE STUDY ABOUT? In their article "Juvenile myoclonic epilepsy 25 years after seizure onset: A population-based study" (Neurology 2009; 73:1041-1045), Drs. Camfield and Camfield studied something that has never been evaluated: how a group of people with this kind of epilepsy do over a long period of time. On the surface, it seems that it would be easy to identify a group of people, follow them for a long time, and then describe what happened to them. However, in our modern world, where people move frequently and sometimes over long distances, long-term studies can be very hard-if not impossible - to do.

Working in Nova Scotia, Drs. Camfield and Camfield identified people with JME. They looked carefully at their medical records to be certain that the group did not have another kind of epilepsy. For instance, the people could have had a generalized tonic-clonic seizure, but mainly were experiencing myoclonic seizures. Medical testing, such as an electroencephalogram (EEG), had to show the kind of abnormality that occurs in this kind of epilepsy (called a 3-hertz spike-and-wave pattern). Of course, the history, such as the age at onset, and a possible family history of epilepsy was carefully reviewed.

After all of these conditions were met, Drs. Camfield and Camfield had identified 24 people with JME. To find this group, the doctors reviewed the medical records of anyone who had been diagnosed with epilepsy between 1977 and 1985. Remember, they wanted to see how these people were going to do over 25 years, so they had to look back to the 1970 s and 1980s to find people who would have had epilepsy for that period of time. They narrowed the group to only those with JME, using the criteria above.

All of the case files were reassessed between 2007 and 2008. The doctors also called the 24 people and asked them questions over the telephone. In this way, they were able to confirm what the records said and were able to make sure that there were no errors. The questions were posed in a formal interview style, and everyone was asked the same questions in the same way to make sure that the results were free from any biases. The doctors asked how well the group had done in school, whether they had a job, whether or not they had been married, and whether or not they had children. The reason for these personal questions was to determine if the epilepsy might affect whether or not a person could finish school, get a job, and maintain a relationship.

WHO WERE THE PARTICIPANTS? The entire group had generalized tonic-clonic and myoclonic seizures (remember, this was one of the criteria they used to make the diagnosis). All of the people had been treated with antiseizure medications. Eight of the $24(35 \%)$ had a serious kind of seizure called status epilepticus - this is a medical emergency. Three of the 24 (about 12\%) had seizures that did not respond well to medications.

The other $88 \%$ had seizures that either responded to medications or went away on their own. More specifically, $17 \%$ were taking no medications and were not having seizures of any kind 25 years after the diagnosis of JME was made. Thirteen percent were taking no medication and had only myoclonic seizures. Since myoclonic seizures are very brief (see table 1), lasting only part of 1 second, most people experience no problems when these occur. Furthermore, the myoclonic seizures tend to occur in the early morning, within the first few hours of waking up. In other words, people with JME do not usually have their myoclonic seizures all day long.

\section{Table 1 Types of generalized seizures}

Absence seizures: Brief, usually 10-20 seconds. The person will stop what he or she is doing, and complete loss of consciousness occurs. Occasionally, the person will have rhythmic eye blinking or demonstrate automatisms. This type of seizure can be brought on with hyperventilation, which is sometimes used as a confirmatory "test" during a doctor's visit. The EEG shows a 2.5- to $4-\mathrm{Hz}$ generalized discharge during the absence seizure.

Myoclonic seizures: These are very brief, often described as "split-second" by the patient. They consist of sudden shock-like muscular jerks, often involving both sides of the body at the same time. The EEG shows a complex generalized discharge often referred to as a polyspike when the myoclonic seizure occurs.

Generalized tonic-clonic seizures: These usually last 2-3 minutes (though the postictal confusion can last longer and is often confused with the seizure itself). The tonic or stiffening phase of the seizure is first, lasting 10-30 seconds. This is followed by clonic movements, which are rhythmic symmetric contractions of muscle groups. The EEG shows characteristic generalized discharges that evolve simultaneous to the clinical manifestations. 
After 25 years, about three-quarters (65\%-77\%) reported that they were "very satisfied" with their health, friendships, and social life; $87 \%$ were high school graduates, and $70 \%$ had gone on to higher education; 69\% were currently employed "with enough income to be self-sufficient"; 9 people were taking medication for depression or anxiety, common problems that affect many people with epilepsy.

The authors acknowledge that the number of people in their study is small. Because of the small size of the group, they were unable to study what factors might help doctors to predict which person will become seizure-free. This finding is in direct opposition to what many earlier papers had said: that the seizures in JME never go away on their own.
WHY IS THIS STUDY IMPORTANT? Doctors use many different kinds of studies to make decisions about the best way to counsel patients about their illness. Some studies demonstrate the effectiveness and safety of a specific treatment. Others might highlight certain problems that a treatment may cause. Using studies like the one by Drs. Camfield and Camfield, doctors will have a better understanding of what to expect over a long time. This can have clear implications for how they treat their patients. For instance, how long is treatment needed? When can treatment be stopped? What things in a person's history or on medical testing will help me to decide if I should stop treatment? As of now, we have answers to only some of these questions. However, as research continues, we may begin to answer the remainder. 
Section Editors

David C. Spencer, MD

Steven Karceski, MD

\section{About juvenile myoclonic epilepsy}

WHAT IS JME? JME stands for juvenile myoclonic epilepsy. The name of the illness describes it well. JME is a kind of epilepsy that starts in adolescence (in other words, juvenile). In JME, the main kind of seizure that a person experiences is a myoclonic seizure. These are very brief, often described as "splitsecond" seizures that cause jerks of the arms more than the legs. Often, myoclonic seizures happen when people first wake up, causing them to drop their toothbrush, or drop the shampoo bottle (if they happen to shower first thing in the morning).

However, people with JME can have more than one kind of seizure. Often, they will experience generalized tonic-clonic seizures as well, though these usually occur less often than the myoclonic seizures (table 1). Generalized tonic-clonic seizures begin with stiffening, which is followed by shaking of both arms and legs. A person is unconscious during these, and the seizure might cause the person to fall and become injured. It is common for a person to visit a doctor after a tonic-clonic seizure. In fact, a person with myoclonic seizures could easily dismiss them because they are so brief. It is only after the "bigger"

\begin{tabular}{|c|c|c|}
\hline \multicolumn{3}{|c|}{ An overview of treatment options for generalized seizures } \\
\hline Seizure type & Medications improve & $\begin{array}{l}\text { Medications that have been } \\
\text { reported to worsen }\end{array}$ \\
\hline Absence & $\begin{array}{l}\text { Ethosuximide, felbamate, lamotrigine, } \\
\text { levetiracetam, topiramate, valproate, } \\
\text { zonisamide; clobazam and } \\
\text { acetazolamide may be effective as } \\
\text { adjuncts; vagus nerve stimulation is } \\
\text { less well studied, but may be effective } \\
\text { in refractory idiopathic epilepsy } \\
\text { syndromes; a new medication, } \\
\text { rufinamide, has not yet been studied in } \\
\text { this kind of epilepsy, but is thought to } \\
\text { work as well. }\end{array}$ & $\begin{array}{l}\text { Carbamazepine, phenytoin, } \\
\text { vigabatrin, tiagabine }\end{array}$ \\
\hline Myoclonic & $\begin{array}{l}\text { Felbamate, lamotrigine, levetiracetam, } \\
\text { topiramate, valproate, zonisamide; } \\
\text { vagus nerve stimulation is less well } \\
\text { studied, but may be effective in } \\
\text { refractory idiopathic epilepsy } \\
\text { syndromes; a new medication, } \\
\text { rufinamide, has not yet been studied in } \\
\text { this kind of epilepsy, but is thought to } \\
\text { work as well. }\end{array}$ & $\begin{array}{l}\text { Carbamazepine, gabapentin, } \\
\text { oxcarbazepine, } \\
\text { phenobarbital, phenytoin, } \\
\text { primidone }\end{array}$ \\
\hline $\begin{array}{l}\text { Generalized (from } \\
\text { onset) tonic-clonic }\end{array}$ & $\begin{array}{l}\text { Felbamate, lamotrigine, levetiracetam, } \\
\text { topiramate, valproate, zonisamide; } \\
\text { vagus nerve stimulation is less well } \\
\text { studied, but may be effective in } \\
\text { refractory idiopathic epilepsy } \\
\text { syndromes; a new medication, } \\
\text { rufinamide, has not yet been studied in } \\
\text { this kind of epilepsy, but is thought to } \\
\text { work as well. }\end{array}$ & \\
\hline
\end{tabular}

seizure that the "smaller" ones are discovered; however, when this combination of seizures occurs, starting in adolescence, the diagnosis is clear.

WHAT CAUSES JME? The cause of JME is genetic, and up to one-half of people who have JME can identify other family members with the same illness. However, not everyone with JME knows someone in their family who has seizures. A person can have the gene, but never have seizures. Another way of thinking about this is that some people are "carriers" of the gene-for them, the gene is "silent." However, they can still pass the gene to their children. Their children may (or may not) ever show the gene, meaning that many people in a family could have the gene, but only a few of them will have seizures. So far, several different genes have been identified as possible causes for JME.

WHO DEVELOPS JME? JME can begin between the ages of 6 and 36, though for most people the seizures begin between the ages of 12 and 18 . Why JME starts in adolescence is unclear, though some have proposed that the "trigger" is hormones. The reason for this is that the onset of the seizures coincides (for most people) with the physical changes that occur in puberty: hair growth, voice changes in men, and breast enlargement in women.

HOW IS JME DIAGNOSED? As part of the evaluation for seizures, a doctor will order an electroencephalogram (EEG). This is a test that measures brain waves. When a person has seizures, his or her brain waves may show certain patterns. Although these patterns are not seizures, they are markers of seizures. In JME, a specific EEG pattern often occurs. It is called a "3-hertz spike-and-wave" which describes what it looks like when the EEG is reviewed.

HOW IS JME TREATED? The main treatment of seizures is medication. Today, many medications are available for the seizures that occur in JME (table 2). In JME, the seizures usually respond to low doses of medication. Since side effects occur more often at high doses of medications, this means that most people with JME will experience good seizure control with- 
out side effects. However, a person with JME also needs to avoid triggers for seizures by getting plenty of rest and avoiding overindulgence in alcohol.

In short, JME is a genetic epilepsy that causes seizures which begin in adolescence. Although people with JME may experience three kinds of seizures (generalized tonic-clonic, myoclonic, and absence), the one that they have most often is myoclonic. Most people with JME will stop having seizures if they take medications and avoid seizure triggers. Although doctors used to think that JME was life-long, studies like the one by Camfield and Camfield say otherwise: that up to one-third of people with JME may either be seizure-free or have myoclonic seizures only. In other words, life-long medication may not be needed. However, more study is required before doctors can predict which people with JME become seizure-free, and who might need lifelong medication.

\section{FOR MORE INFORMATION}

The Brain Matters

http://www. thebrainmatters.org

Epilepsy Foundation

http://www.epilepsyfoundation.org/ 


\section{Neurology}

\section{Juvenile myoclonic epilepsy, a common epilepsy syndrome \\ Steven Karceski \\ Neurology 2009;73;e64-e67 \\ DOI 10.1212/WNL.0b013e3181bd13f1}

This information is current as of September 28, 2009

\section{Updated Information \&}

Services

Permissions \& Licensing

Reprints including high resolution figures, can be found at: http://n.neurology.org/content/73/13/e64.full

Information about reproducing this article in parts (figures,tables) or in its entirety can be found online at:

http://www.neurology.org/about/about_the_journal\#permissions

Information about ordering reprints can be found online:

http://n.neurology.org/subscribers/advertise

Neurology ${ }^{\circledR}$ is the official journal of the American Academy of Neurology. Published continuously since 1951, it is now a weekly with 48 issues per year. Copyright . All rights reserved. Print ISSN: 0028-3878. Online ISSN: 1526-632X.

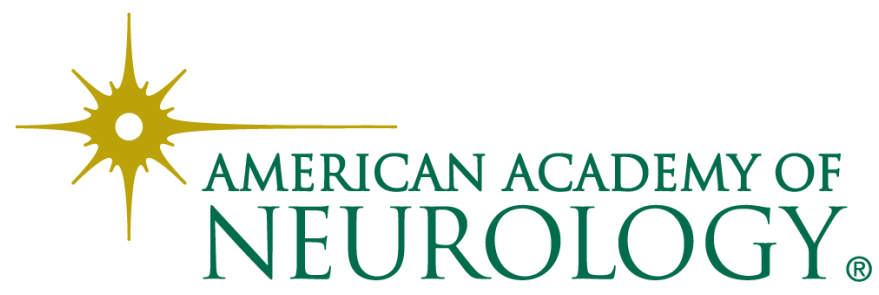

